\title{
Author Index Volume 8 (1996)
}

The issue number is given in front of the page numbers.

Information for authors

(2) $187-192$

Adriaansens, M.A.M., Post marketing surveillance on medical implants: legal aspects on patient tracking

Andersen, B.S., H.P. Jensen, L.C. Borris, M.R. Lassen, T. Mätzsch, D. Bergqvist, B.I. Eriksson and C. Tørholm, Survival in patients undergoing total hip arthroplasty in relation to thromboprophylaxis with low molecular weight heparin: a long-term follow-up study

(1) $71-76$

(3) $251-259$

Bates, J., see Page, G.G.

Bazire, N., see Shakespeare, P.G.

Berg, H.M. van den, The opinion of a manufacturer

Bergqvist, D., see Andersen, B.S.

Black, J., Implant retrieval: an overview of goals and perspectives

Black, J., Overview of PMS in an international perspective: global developments and global cooperation

Bordage, G., see Page, G.G.

Borris, L.C., see Andersen, B.S.

Buma, P., Retrieval analysis of orthopaedic implants. Tissue reactions around a hydroxyapatite coated hip prosthesis

(3) $217-224$

(1) $79-83$

(1) $61-63$

(3) $251-259$

(1) $99-104$

(1) $3-8$

(3) $217-224$

(3) $251-259$

(1) $111-117$

Conradi, M., K. Groenier, J. Hutten, J. Schuling, T. Tijmstra and B. Meyboom-de Jong, Complications and side effects: a problem in general practice?

Cornel, M.C., J.D. Erickson, M.J. Khoury, L.M. James and Y. Liu, Population-based birthdefect and risk-factor surveillance: data from the Northern Netherlands

(3) $225-230$

(3) $197-120$

Dalla-Vorgia, P., see Lascaratos, J.

(3) $231-236$

Decoulx, J., see Hildebrand, H.F.

(1) $125-134$

Duquennoy, A., see Hildebrand, H.F.

(1) $125-134$

Dyer, S.M., see Page, G.G.

(3) $217-224$

Eisenmann-Klein, M., see Nicolai, J.-P.A.

El Nahhal, K. and C. Savona-Ventura, Obesity and its obstetric implications

Erickson, J.D., see Cornel, M.C.

(1) $47-50$

(2) $141-147$

(3) $197-120$

Eriksson, B.I., see Andersen, B.S.

(3) $251-259$

Faro, L.M.C., Guest-editorial: Post marketing surveillance for implants

Faro, L.M.C., see Nicolai, J.-P.A.

Feruglio, G.A., Euro-registration of pacemakers: state-of-the-art 1993

(1) $1-1$

(1) $47-50$

(1) $51-53$

(2) $149-167$

Floquet, I., see Hildebrand, H.F.

(2) $137-140$

Fonager, K., see Sørensen, H.T. 
Gerrett, A., see Shakespeare, P.G.

(1) $79-83$

Groenier, K., see Conradi, M.

(3) $225-230$

Grøn, P., see Sørensen, H.T.

(3) $243-250$

Herberts, P., see Malchau, H.

Hildebrand, H.F., Statistical evaluation of the loosening of total hip replacement

(1) $27-45$

Hildebrand, H.F., I. Floquet, A. Lefèvre and C. Véron, Biological and hepatotoxic effects of palladium. An overview on experimental investigations and personal studies

(1) $109-110$

Hildebrand, H.F., P. Laffargue, J. Decoulx, A. Duquennoy and H. Mestdagh, Retrieval analyses of total hip replacements

Homsy, C.A., Concept and practice of implant vigilance in the USA

Homsy, C.A., Consequences of implant failure caused by surgical treatment

Hutten, J., see Conradi, M.

(2) $149-167$

(1) $125-134$

(1) $93-98$

(1) $9-18$

(3) $225-230$

Iancu, I., B. Spivak, A. Wiener and A. Weizman, Psychiatric guidelines for licensing drivers

(2) $169-173$

Jacques, A., see Page, G.G.

James, L.M., see Cornel, M.C.

Jensen, H.P., see Andersen, B.S.

(3) $217-224$

(3) $197-120$

(3) $251-259$

Kaigas, T., see Page, G.G.

Kaplan, B., see Merlob, P.

Khoury, M.J. , see Cornel, M.C.

Knapp, T.R., Long-term medical device accountability: an information technology solution

Kopelow, M., see Page, G.G.

(3) $217-224$

(3) $237-242$

(3) $197-120$

(1) $85-91$

(3) $217-224$

Laffargue, P., see Hildebrand, H.F.

Lascaratos, J. and P. Dalla-Vorgia, Defensive medicine: two historical cases

(1) $125-134$

(3) $231-236$

Lassen, M.R., see Andersen, B.S.

Lefèvre, A., see Hildebrand, H.F.

Legemaate, J., Legal aspects of Euro legislation: border crossing transfer of data

Levi, N., Reoperations of cervical hip fractures: increase risk of wound infection?

Levi, N., H. Sillesen, T.G. Nielsen and T.V. Schroeder, Preoperative mapping of the saphenous vein: Predicting the risk of failure of infrainguinal bypass surgery

Lilley, R., The Robin's dance

Liu, Y., see Cornel, M.C.

Malchau, H. and P. Herberts, Prognosis of total hip replacement

Mätzsch, T., see Andersen, B.S.

McNeill, D.C., see Shakespeare, P.G.

Merlob, P., B. Stahl and B. Kaplan, Children born to mothers using multiple drug therapy during their pregnancy

Mestdagh, H., see Hildebrand, H.F.

Meyboom-de Jong, B., see Conradi, M.

Miller, D.M., Misconceptions about the role of medical device regulations and their resultant impact on the effectiveness on medical devices

Mol, B.A.J.M. de, Retrieval analysis of cardiovascular implants

Moran, J., see Page, G.G.

(3) $251-259$

(2) $149-167$

(1) $55-59$

(3) $211-216$

(2) $175-177$

(3) $261-262$

(3) $197-120$

(1) $27-45$

(3) $251-259$

(1) $79-83$

(3) $237-242$

(1) $125-134$

(3) $225-230$

(1) $19-25$

(1) $119-123$

(3) $217-224$

Nicolai, J.-P.A., M. Eisenmann-Klein and L.M.C. Faro, Towards a European Registry of Implants in Plastic Surgery

Nielsen, G.L., see Sørensen, H.T.

(1) $47-50$

(3) $243-250$ 
Nielsen, T.G., see Levi, N.

(2) $175-177$

Norman, G.R., see Page, G.G.

Nouwen, J.J., Implant and patient tracking: the opinion of a patient

(3) $217-224$

(1) $67-69$

O’Donovan, M., Awareness under general anaesthesia - a clinical risk management perspective

(3) $193-196$

Page, G.G., J. Bates, S.M. Dyer, D.R. Vincent, G. Bordage, A. Jacques, A. Sindon, T. Kaigas, G.R. Norman, M. Kopelow and J. Moran, Physician-assessment and physicianenhancement programs in Canada

(3) $217-224$

Savona-Ventura, C., see El Nahhal, K.

Schouten, L., Application of bar coding in hospitals. Pilot study: the use of bar code on OR sutures in the University Hospital Leiden, The Netherlands

Schroeder, T.V., see Levi, N.

Schuling, J., see Conradi, M.

Shakespeare, P.G., N. Bazire, D.C. McNeill and A. Gerrett, The United Kingdom Breast Implant Registry

Sillesen, H., see Levi, N.

Sindon, A., see Page, G.G.

Sørensen, H.T. and K. Fonager, Risk estimation of disorders associated with coeliac disease. A 16-year Danish nationwide follow-up study based on hospital discharge data. Implications for screening

Sørensen, H.T., F.H. Steffensen, G.L. Nielsen and P. Grøn, Variation in antibiotic prescribing costs in Danish general practice: an epidemiological pharmaco-economic analysis

Spivak, B., see Iancu, I.

Staal, M.J., Post marketing surveillance on medical implants in neurosurgery

Stahl, B., see Merlob, P.

Steffensen, F.H., see Sørensen, H.T.

(2) $141-147$

(1) $77-78$

(2) $175-177$

(3) $225-230$

(1) $79-83$

(2) $175-177$

(3) $217-224$

(2) $137-140$

(3) $243-250$

(2) $169-173$

(1) $65-66$

(3) $237-242$

(3) $243-250$

Tempelaar, A.F., Safety and risk in practice

Tempelaar, A.F., Safety and risk in practice

(2) $179-185$

(3) $263-272$

(3) $225-230$

Tijmstra, T., see Conradi, M.

Tørholm, C., see Andersen, B.S.

(3) 251-259

Véron, C., see Hildebrand, H.F.

(2) $149-167$

Vincent, D.R., see Page, G.G.

(3) $217-224$

Weizman, A., see Iancu, I.

(2) $169-173$

Wiener, A., see Iancu, I.

(2) $169-173$

Williams, D.F., Professional standards in failure analysis and expert reports

(1) 105-107 